Openings and Retrospectives

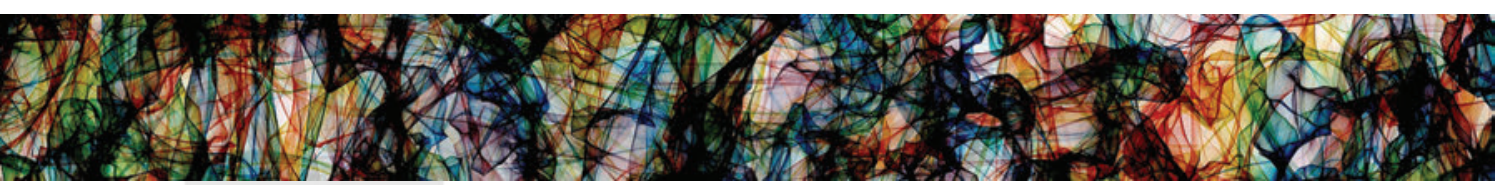

REFUSAL AS ACT, REFUSAL AS ABSTENTION

\title{
ERICA WEISS
}

Tel Aviv University

(D) http: / / orcid.org/0000-00002-7047-6712

To refuse is usually thought of as saying no, but is it possible to refuse by saying nothing at all or by averting your eyes? Can you refuse by tossing a summons in the trash bin? How would these acts change the political implications of refusal? Before I arrived in the field to work with Israelis who refuse to serve in the military for reasons of conscience, I thought that I understood who belonged to this group. The Israeli and international media had profiled many refusers, who themselves were equipped with web sites and promotional literature. But I found that in addition to these public refusers, there were also those who evaded military service without ever formally declaring their refusal. In fact, those who declared their refusal constituted only a tiny percentage of those who refused military service. The public refuser movement was, and is, only the tip of the iceberg, the visible part of a practice whose invisible proportions dwarf its public face. With time, I also came to appreciate that while declaring refusal is an act of defiance against the state, silent refusal is a form of abstention. Here, I argue for the radical potential of refusal as abstention. While public military refusal can be understood as resistance, refusal as abstention should be understood as an affir- 
mative investment in another possibility. In my understanding, abstention is calculated passivity, and it is no coincidence that abstention likewise characterizes all the cases of refusal raised in this Openings collection, be it not showing up at the voting booth, the passport office, the doctor's office, or the military enlistment center. Abstention, a tense stillness that hopes to avoid the state's gaze, is a kind of "playing dead" to avoid the traps of citizenship.

In Israel, public military refusal carries the potential for social transformation by being cast as a political and moral act of the individual. Public declarations of refusal receive significant attention from the media, and as a result become known to the broader society. Such declarations can influence public discourse. Israelis have been able to use public refusal as a stage for political intervention and activism. They have managed to create doubt in the Israeli mainstream about the ethical and legal legitimacy of the Israeli military and state's actions. In addition, they have attracted international attention. Public intellectuals such as Susan Sontag (2004) and Slavoj Žižek (2002) have written admiring accounts and philosophical reinforcement in support of Israeli military refusers. "Resistance to crimes of state, and refusal to participate in them, has been and remains one of the most significant achievements of people of decency and courage throughout history. The Israelis who have undertaken this honorable course merit the greatest admiration and respect," wrote leftist pietist Noam Chomsky in praise of a collection of refusenik writings (Kidron 2004, back cover). In contrast, those who evade military service, whose refusal remains below the surface, do not have the same public impact. They stay unadored, uncelebrated. Their refusal is, rather, a quiet groundswell of abstention. These refusers' motivation resembles that of other groups considered in this Openings collection: the decision to invest their hopes and energies elsewhere. In contrast to public military refusal, abstention avoids the state's resistance trap, which dooms public refusal to be claimed and co-opted by the state.

\section{UNINTENTIONAL CONSCRIPTION}

Any individual who publicly refuses is subjected to a military evaluation of his or her claims. But first, all refusers are put into military uniform and sent before a sentencing officer. This signals the state's declaration that the individual is not a citizen refusing to enlist, but rather a soldier refusing an order to complete the recruitment process, an offense against Section 122 of the Military Code of 1955. By sleight of hand, the military defines the default position as conscription, against the intentions of the refuser. This move simultaneously represents a cun- 
ning conscription into the state project itself. The Israeli state sends the order to enlist in the military through the national postal service. The state desires that the young person will respond positively to this request for consent. The public military refuser's intention is to reject the state and deny its authority. But the state appreciates better than the refuser that any response to its order to enlist, whether yes or no, constitutes an explicit recognition of the state's right to request consent. Thus the declaration of "no" falls into the state's well-laid trap.

Despite the opportunity for more effective political intervention, public refusal places a particularly heavy burden on those who practice it, and actually provides the state with the opportunity to nullify its intended effects and conscript the refuser into the purposes of the state project. Individuals have sparse opportunities to refuse consent, and while the intent of public refusal is to reject state authority, the state proves very sly. Audra Simpson (2016) demonstrates how the state often manipulates interpretive possibilities in its own favor. In the case of Israeli military refusers, the state uses the moment of refusal as an opportunity to conscript individuals into recognizing the authority of the state, even if they are not ultimately conscripted into the military.

Though those who declare their refusal to serve in the Israeli military imagine their act to constitute the ultimate rejection of the state, in some ways they are also pulled into unintentional identification with the state project. The selfsacrificial aspect of public refusal in particular often forms part of this unintentional affiliation with the state. In contrast to those who evade service, those who refuse publicly generally serve time in jail. This time in prison is understood as an act of sacrifice, ultimately for the national good. Serving in jail, even if to protest the state's actions, recognizes the state project and is often understood by the Israeli public as a patriotic act because the refusers willingly sacrifice for their political beliefs (Weiss 2014). On inspection, we find that the recognition is mutual: the refuser recognizes the state project, while the state recognizes the refuser as worthy of jailing. As we will soon see, many groups are not asked to serve, and thus do not have access to the position of a public refusal. Thus, the punishment refusers receive constitutes a kind of state recognition of social worth, demonstrating the problematic entanglement of public refusal in state forms of recognition.

\section{TESTS OF AUTONOMY}

State forms of recognition entailed in public refusal also include submission to an assessment of one's capacity for moral autonomy. Moral autonomy is not 
at issue when one consents to state authority. However, a declaration of refusal is an act of dissent that requires a person to demonstrate his or her conformity with liberal expectations of self-authorization. Freedom of conscience, the main claim of those who publically declare their refusal, relies on the principle of selfauthorization. Conscience is understood as an internal guide only accessible to the individual through reflection. As such, the social expectation is that one must be accountable to one's own moral insight. Yet this freedom from external injunction comes with several caveats.

When one finds oneself in a moment of public refusal, one's capacity for moral autonomy, something taken for granted before refusal, is interrogated intensely. This interrogation is conducted through a synergetic partnership of the military and the mainstream media, both examining the lives and histories of refusers in search of disqualifying evidence. The public evaluation of one's capacity to take such a stand can be affected by any number of conditions, which do not need to rise to any legal threshold to find one lacking in the court of public opinion. A medical condition, past or present drug use or illegal activity, a disability, being a woman or a gay person - all of these are reasons for people to conclude that one's motivations for refusal are not ethical. ("It's not conscience, she's just crazy!" [he pashut meshuga'at]; "he's from a weak population/unstable family," “economic reasons," “drugs," etc.).

So it is no coincidence that only the most hegemonic of Israeli citizens become public military refusers. This group is composed of able-bodied, cleancut, wealthy Ashkenazi Jewish males with stellar personal records and nary a parking ticket among them. Of course, this group constitutes a small minority within Israeli society, yet they represent nearly every single public refuser. Thus, one of the privileges of cultural hegemony is the possibility of performing refusal as an act. Some groups are exempted simply because the military does not want them: disabled people, those with medical or psychological issues, the poor, and the uneducated. Most Palestinian citizens are not asked to serve. Many women, even those who try to make public refusals, are simply sent home on the basis of another, often fictitious, exemption such as psychological instability (Weiss 2014). When less archetypal citizens try to make ethical interventions similar to public refusal, they are often besmirched, defamed, racialized, sexualized, and criminalized in a collaboration between the state and the media. ${ }^{1}$

The burden of state recognition also includes satisfying liberal requirements of autonomy and integrity to be considered a genuine case of conscientious refusal. In Life's Dominion, Ronald Dworkin (1993) claims that the key to defining a choice 
as autonomous is its consistency with past choices made by the same individual. This understanding widely informs both liberal legal and colloquial understandings of someone's right to take a moral stance on an issue. If a doctor or nurse refuses, for religious reasons, to perform abortions and seeks to have their right of refusal recognized, in the liberal understanding of rights, their claim will be considered invalid if they are found to have performed abortions in the past, or supported a woman's right to choose, or regularly change their stance on the issue. So, too, are Israeli military refusers subject to this liberal test of integrity. For public military refusers, committees, trials, appeals, and hearings are convened to evaluate the sincerity and consistency of moral claims. ${ }^{2}$

These dynamics could be thought of as a resistance trap. While Sherry Ortner (1995) has pointed to the flattening effects of resistance studies, here I intend to call attention to the ensnaring properties of resistance to the state. Public refusal allows the state to latch on to this act of resistance to its authority through practices of co-optation and appropriation. Refusing the state aloud unwittingly permits the state to control the terms of engagement, bringing in legal and bureaucratic logics, as well as the normative expectations of citizenship, such as loyalty and sacrifice. Much as in quicksand, when operating on the state's terms, the harder you struggle, the deeper you sink. It is this trap that silent refusal avoids, revealing abstention to be a more radical alternative to resistance.

\section{REFUSAL AS ABSTENTION}

While public refusal is the more visible part of the military refusal phenomenon, it is dwarfed by what I am calling refusal by abstention. While public refusal is infrequent and has involved only a few thousand soldiers in peak years, annually nearly half of all Israeli youths do not serve in the military. Some of these forms of refusal are legally accepted. The refusal of Palestinian citizens of Israel is allowed because their service to the Jewish state is generally seen as a contradiction. Religious youths are exempt from service as well, due to a controversial early agreement with the government. But many Israeli youths subject to the draft simply avoid service. These refusers do not declare their refusal; instead, they submit some paperwork, they don't respond to enlistment orders, or they make themselves scarce and wait for further attempts to enlist them. They respond minimally and with as little effort as possible. Eventually, almost everyone who wants to be released is able to avoid service (Weiss 2014). With time, exemptions are handed out that cite such reasons as medical conditions, disability, and generalized incompatibility, though these are often fictitious to varying degrees. 
Sometimes these refusers by abstention first attempt public refusal but remain unsuccessful. In 2001, a group of high-school seniors got together and collectively wrote a letter of refusal, intending to become public refusers. In the end, the young men were jailed, fulfilling their intended goal, while the young women were released from service, unintentionally joining the silent majority of refusers by abstention. For many of the female signatories, this was a watershed moment in which they recognized the trap of state recognition behind refusal. In abstention, one avoids the liberal tests of autonomy that generally serve to pass negative judgment on the individual, rather than on the state as intended. One of these young women, Ruti, told me that she came to see no difference between serving in the military and being a jailed refuser. Both are joining the military system. The true refusal, she told me, would be to avoid the military altogether. Another told me that serving in jail would be a "waste of time," an implicit recognition that public refusal constitutes an investment in the state project. Instead, these women sought to avoid all interaction with the state, and in doing so also avoiding the unintentional nationalism of publicly declared refusal.

The calculated passivity involved in this type of refusal is not the same as being passive, however. Silent refusers see the same abuses as their public counterparts, but they ultimately seek to act through channels other than resistance to the state. These ethical efforts are inevitably more local than public refusal: educational exhibitions drawing attention to the ubiquity of militarism in daily life in Israel; moral and legal support networks for those seeking to refuse through abstention; discussion groups and forums; and other initiatives. These interventions seek to create a parallel public unencumbered by the normative entailments of citizenship in general, and of Israeli citizenship in particular. The proponents of these initiatives do not hold themselves accountable to the state and do not seek to influence matters of policy. Abstention avoids the state rather than challenging it directly. While refusal as abstention from both military service and public proclamation takes place on the individual level, it cannot be measured or valued on the individual level. This is due to the overwhelming numbers of those who abstain, despite their lack of collective organization, as well as the radical potency implicit in their act, despite their lack of manifesto.

\section{A DIFFERENT ACTIVIST GRAMMAR}

In his classic book The Structural Transformation of the Public Sphere, Jürgen Habermas (1989) theorizes a public sphere as a kind of democratic utopia in which individuals can discuss national issues. This idea of the public sphere has 
been challenged on many fronts, including its normative bourgeois character and its dubious claims to emancipatory potential. Indeed, we see these problems manifested in the case of public refusal, as most voices are excluded from this platform, and those who are granted entry are subject to impossible liberal tests of character. State forms of recognition are hegemonic norms that dilute the radical intentions of the refuser. Moreover, the state's use of public refusal as a backdoor conscription strategy serves to further bind the refuser to the state despite his or her intentions.

I argue that, by contrast, refusal as abstention offers a more radical opening. First, these refusers avoid participation in violence. By playing dead as far as the state is concerned, Israeli youths also avoid conscription to the state project, hegemonic liberal tests, and state forms of entrapment. Avoiding the state allows them to invest their ethical intervention elsewhere than in state policy. Like other contributors to this collection, I find that refusal is generative of affiliations not based in citizenship. This can be seen in the nascent bonds of alternative ethical affiliation forming between Ruti and her female cohort, who tried to become public refusers but were sent home as undesirable.

The opening toward other modes of politics begins with the recognition that even in dissent, the public sphere is often only available to the state's most hegemonic citizens. This has sparked an ethical investment in unlearning norms of activism that replicate the problematic politics described above, as well as in building an alternative activist grammar and practices that bypass the state and its demand for self-sacrificial demonstrations ultimately serving state goals. Refusal as abstention has yet to receive odes from international intellectuals, but it has to some extent avoided the rigged norms that activists face in engaging with the state, thus forging a different kind of political space.

Such refusal constitutes an antipolitics in the sense that it seeks to bypass the state. It is a refusal to participate in forms of organized oppression or dissent, rule or revolt, repression or resistance. Refusal as abstention, rather than as struggle and opposition, rejects the hegemonic claim that one must make any ethical intervention through the state and state-level policy. It implicitly yet powerfully rejects the idea that one must speak through one's citizenship. It does not flatter the state by assuming that it is the default source and determinant of just social relationships. It claims that there are publics and ethical life beyond the state, in places that the state cannot reach. As such, abstention avoids the resistance trap of public refusal, which even in its harshest form only reaffirms the state's gravitational pull. 


\section{NOTES}

1. The case of Tali Fahima is a prime example of this process. Fahima, a Mizrahi woman from a poor town in the periphery, challenged the state narrative regarding Palestinian terrorism by initiating contact with a wanted Palestinian in the West Bank. She was eventually charged with "assistance to the enemy at time of war." While military refusers are accorded recognition of their position as a form of ethical stance-taking, Fahima was extended no such recognition. Her sanity was questioned frequently in public discussions, and many attributed her actions to a pathologized sexual relationship with the Palestinian man, despite their mutual denial.

2. The case of Yonatan Ben-Artzi is a prime example of this process. Ben-Artzi was a military refuser who claimed that he should be exempted from service because of his pacifist beliefs. Over the course of several years, committees, trials, appeals, and hearings were convened to evaluate the "secrets of his heart," in the words of one Israeli Supreme Court justice.

\section{REFERENCES}

Dworkin, Ronald M.

1993 Life's Dominion: An Argument about Abortion, Euthanasia, and Individual Freedom. New York: Knopf.

Habermas, Jürgen

1989 The Structural Transformation of the Public Sphere: An Inquiry into a Category of Bourgeois Society. Translated by Thomas Burger, with the assistance of Frederick Lawrence. Cambridge, Mass.: MIT Press. Originally published in 1962.

Kidron, Peretz, ed.

2004 Refusenik! Israel's Soldiers of Conscience. London: Zed Books.

Ortner, Sherry B.

1995 "Resistance and the Problem of Ethnographic Refusal." Comparative Studies in Society and History 37, no. 1: 173-93. http://dx.doi.org/10.1017/ S0010417500019587.

Simpson, Audra

2016 “Consent's Revenge." Cultural Anthropology 31, no. 3: 326-33. http:// dx.doi.org/10.14506/ca31.3.02.

Sontag, Susan

2004 "Foreword." In Refusenik! Israel's Soldiers of Conscience, edited by Peretz Kidron, xi-xvii. London: Zed Books.

Weiss, Erica

2014 Conscientious Objectors in Israel: Citizenship, Sacrifice, Trials of Fealty. Philadelphia:

Žižek, Slavoj University of Pennsylvania Press.

2002 “Are We in a War? Do We Have an Enemy?" London Review of Books 24, no. 10: 3-6. http://www.lrb.co.uk/v24/n10/slavoj-zizek/are-we-in-a-war-do-wehave-an-enemy. 